\title{
Design Science: Approach to Build Design Thinking for Student
}

\author{
Winta Adhitia Guspara \\ Design Product Department, Faculty of Architecture and Design, UKDW Yogyakarta \\ Jl. dr. Wahidin Sudirohusodo, No. 5-25, Yogyakarta 55224 \\ E-mail: guspara@staff.ukdw.ac.id
}

\begin{abstract}
The existence of products (artifacts) was not a major element in the design paradigm. Product is like tools to help for designing scenarios, realizing the future, and building design knowledge. Planning and making of a product should have an interconnection between the user, product and environment (e.g. space, social, ecological). Accordingly, three main aspects work on the interconnection of product existence. First is the "action" aspect that the product created when changing user behavior. The second is the aspect of "matter" which talks about functions and purpose to meet user needs. The third is the aspect of "limitation" that arises when every limitation, need, and behavior meets each other. There is one important thing in that discourse, which is how the three aspects (i.e. action, matter, limitation) work and they are interconnected to build of the three design goals (i.e. scenario, future, design knowledge). The fundamental problem for product development was the gap between design theory and design practice. This situation occurs because the development of a product has been moving from the past and present until the future. The issue of conditions and time could not be done through sketches, visual images or also involving tinkering processes involving components and materials. Relied on that, this article invites us to discuss design in a frame of mind called design science. The background of this discussion is an activity, process and design thinking that takes place and address product design students when developing a product. The goals to be achieved through this article is to get compatible design knowledge between the theory (head) and practical aspects (hands).
\end{abstract}

Keywords: design science, design knowledge, design thinking, product development

\section{Design Science: Pendekatan untuk Membangun Cara Berpikir Desain bagi Mahasiswa}

\section{ABSTRAK}

Keberadaan produk (artifak) bukan merupakan unsur utama dalam paradigma desain. Produk lebih merupakan alat untuk merancang skenario, mewujudkan masa depan, dan membangun pengetahuan desain. Perancangan dan pembuatan sebuah produk harus dapat menghubungkan antara pengguna, produk dan lingkungan (e.g. ruang, sosial, ekologi). Berdasar hal tersebut, terdapat tiga aspek utama yang bekerja pada hubungan keberadaan produk. Pertama yaitu aspek "action" yang ditimbulkan oleh produk ketika merubah perilaku pengguna. Kedua ialah aspek "matter" yang berbicara mengenai fungsi dan tujuan untuk memenuhi kebutuhan pengguna. Ketiga ialah aspek "limitation" yang muncul ketika setiap 
keterbatasan, kebutuhan, dan perilaku saling bertemu. Terdapat satu perkara penting dalam wacana di atas yaitu bagaimana ketiga aspek (action, matter, limitation) bekerja dan saling terhubung untuk membangun ketiga tujuan desain (skenario, masa depan, pengetahuan desain). Masalah mendasar untuk pengembangan produk adalah kesenjangan antara teori desain dan praktik desain. Situasi ini terjadi karena pengembangan suatu produk bergerak pada masa lalu, sekarang, dan kedepan. Persoalan kondisi dan waktu ini tidak bisa hanya dilakukan melalui sketsa, gambar visual atau juga melibatkan proses utak-atik yang melibatkan komponen dan bahan. Berdasar pada hal itu, maka artikel ini mengajak untuk membahas desain dalam sebuah kerangka pemikiran yang disebut sebagai design science. Latar belakang pembahasan yang digunakan ialah aktivitas, proses dan berpikir desain yang berlangsung pada mahasiswa ketika melakukan pengembangan sebuah produk. Hasil yang ingin dicapai melalui artikel ini ialah mendapatkan pengetahuan desain yang kompatibel antara teori (kepala) dan aspek praktis (tangan).

Kata Kunci: design science, pengetahuan desain, berpikir desain, pengembangan produk

\section{INTRODUCTION}

Relied on the fundamental learning of humans that was well-constructed by transposes meaningless feelings into meaningful ones (i.e. tacit knowledge) (Polanyi, 1966), I would like to begin with a brief review of Indonesian terminology as known as "reka-yasa" (rekayasa). According to the Indonesian language dictionary (KBBI), reka means organizing, arranging, planning, presuming, expect. While, yasa on Indonesian-Java dictionary means inventive, making, made in, fabricating, manufacture, to wrought out. In other words, rekayasa (KBBI) has a meaning as the implementation/application of knowledge into a practical field/to execute/to make do/an order. Grounded in my study of tacit knowledge (Guspara, 2018 (a); Guspara, 2018 (b); Guspara, 2018 (c); Guspara, 2018 (d); Guspara, 2019), rekayasa has described as arranging/gave a thought to mapping out a model, pattern, situation, condition, problem, form, the structure into an activity of building up or making.

Today, we are living in the man-made world (i.e. rekayasa) than it is a natural world. Our activity daily living shown that almost every aspect of us depends on human artifacts, start from toothpaste until humidity which is produced by the air conditioner (Simon, 1996). However, the man-made world could not be neglected from human activity when they faced their problem to survive, and we called that activity as a design. For example, the artifact of archaeology shown us the design activity while the ancient people made a stone sickle blade for harvesting (Goodale et al., 2009) or cooking stove (Nystoom, 1985). The matter of fact, the design had a strong contribution to a man-made world, and product to be one of the 
important things in these circumstances. Start from this opinion, the design would be generated from the craftmanship era (i.e hands-on) to the draughtsmanship era (i.e. design process) when the industrial design had been started. The world situation today, design, as well as industrial design, can not speak about the product as it is a goal anymore. There is any situation or scenario that we have to change or build using the product, and some of the views we must deal with a wicked problem (Rittel, and Webber, 1984). A question in design study related to this situation is 'what is the next an essential constraint when the design has passed through a handson process and design process, and how we teach the student to face it'.

To answer that question, I would like to discuss a body of design knowledge through a design science perspective which is an approach to bridge tacit knowledge toward creativity or particularly about a practical activity (i.e. knowhow) and into knowing (i.e. know-what) (Ryle, 2009; Holmstrom et al., 2009). Following Simon and Wieringa there is any two of a kind prominent situation in design science, that is (1) practical problem which following with a design question and addressed for a change the world, and (2) research problem which have a knowledge question and deal with a change knowledge about the world (Simon, 1996; Wierenga, 2009). Both of them have interaction with each other, as it is a combination of methods in design activity.

\section{METHOD}

According to Simon, the design is a relationship between attaining goals with devise artifacts and concerned with how things ought to be (Simon, 1996). So this study focuses on what should have any for produce knowledge by creating a product and how a learning strategy to following it. The most important aspect of them is the logic of design which born from finding alternatives through synthesized. Hence, this study used action research methods (Somekh, 2008) to continued a rationale from Simon thought. For doing this (fig. 1), I work in any collaborated with a few students to finish our project for creating a product (e.g. studio class, exhibition project). 


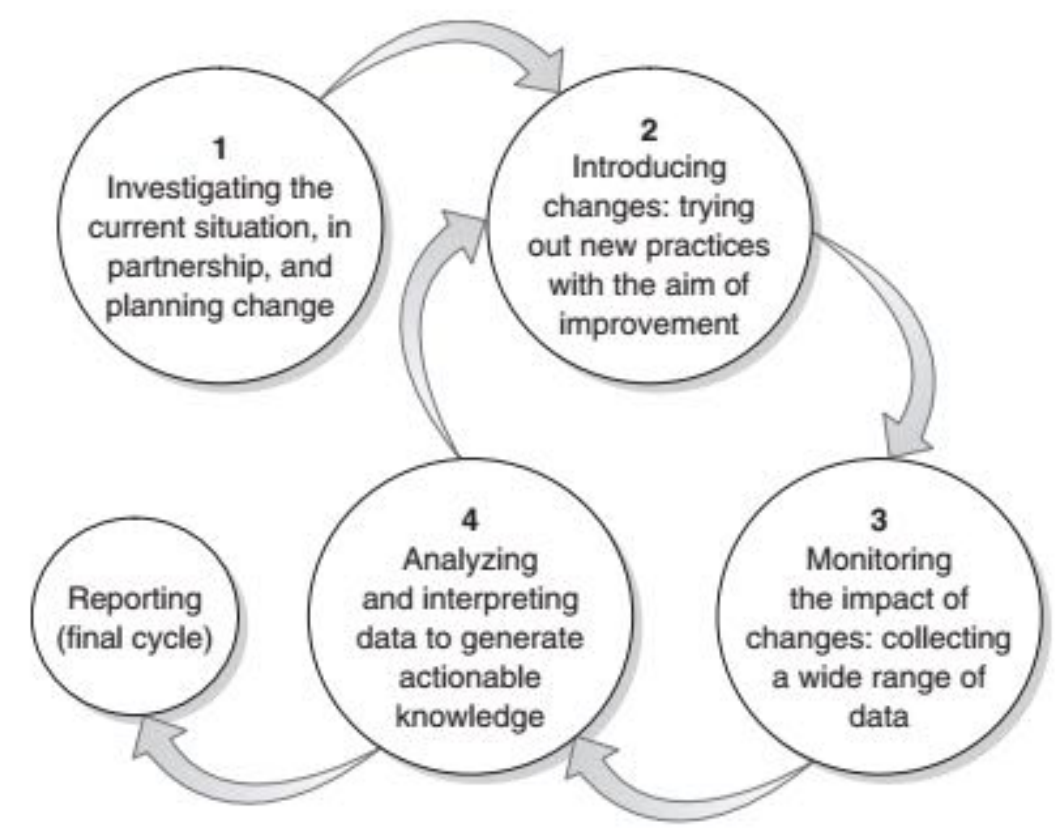

Figure 1. Model of Action Research Source: Somekh, 2008

Step 1: To find what students have, we had brainstorming to found out of theme for their project. In our discussion, I laid on a parameter which is the urgency of theme, a problem or situation that has to be done, and people who had a contribution to work with. Usually, I asked the student to found out the relationship between their theme, design issues, SDGs view, national agenda, and a situation around them.

Step 2: There are two kinds of situations in design activity, which are (1) research problem and (2) design problem. So, I will ask the student to found out the gap between the needs and the situation ought to be. There is two way that student able to do, (1) found out through literature (i.e. journal, article, book) or (2) found out using creating prototype and tested.

Step 3: Starting from what the student decides, we look back at the problems found and the goals to be addressed. The process will lead students in difficult situations, especially looking for real problems and alternative solutions. Sometimes, students need other methods to achieve it, but they don't know the exact method and the correlation between the methods.

Step 4: The next process is iteration and refinement, in the form of making a prototype that continued with testing or testing of the prototype that followed by reviewing the theory used. 
Winta Adhitia Guspara, Design Science: Approach to Build Design ...

Step 5: The final report writing has done through reflection and synthesis which involves the relationship of every single step in design activity.

\section{Practical Work}

This article is based on work on studio classes and competition projects. The students have involved ranged from twenty-two people with different themes, namely (1) studio class with inclusive design theme, (2) competition projects with the disaster preparedness theme. Particularly, the project re-usable material and disaster preparedness projects were not only followed by product design students but also involve students from information technology, medical education, and biotechnology.

\section{Studio Classes}

This studio class has laid on the ergonomics approach as the basis for design activities and the chosen theme is designed inclusively. The basic understanding of ergonomics in design has been obtained in previous classes, so this class is an intermediate class based on research to get product novelty. As well as the studio class, the initial session begins with introducing the following inclusive design with an intended population and extreme users as respondents. Besides, our initial discussion talked more broadly about the relationship between the Sustainable Development Agendas, the Indonesian National Agendas, and the phenomena around us. An example is a relationship between an increasing number of elderly demographics, available products, and productivity. On behalf of ergonomics in design, those talked refers to elderly behavior, product usage, anthropometry, body mechanics, and gaps that arise.

In this process, students are not only asked to know the phenomena that occur but also found design problems. The case at this stage is students often do not know that getting data in every aspect requires a variety of methods which interrelated with. Therefore, we need a strategy that students able to know the methods needed and understood the purpose of the method. For example, it is a case when the elderly doing clothes washing activity at the nursing home. At this stage, students will make observations toward habits of clothes washing, body posture, and product usage without any understanding of the tools and methods that should be used to conduct research. The initial information that can be collected by students in the elderly is doing the washing activity without a washing machine. The activity has lead to various complaints most like back pain, fatigue in the shoulder, and numb on the hands. The results are not wrong, but very often students cannot find a more specific relationship to the information obtained. Refer to this case, students were asking to make problem mapping has shown in figure 2 , which has contained 
a next propose and method to be used for research which has shown in figure 3 for an example.

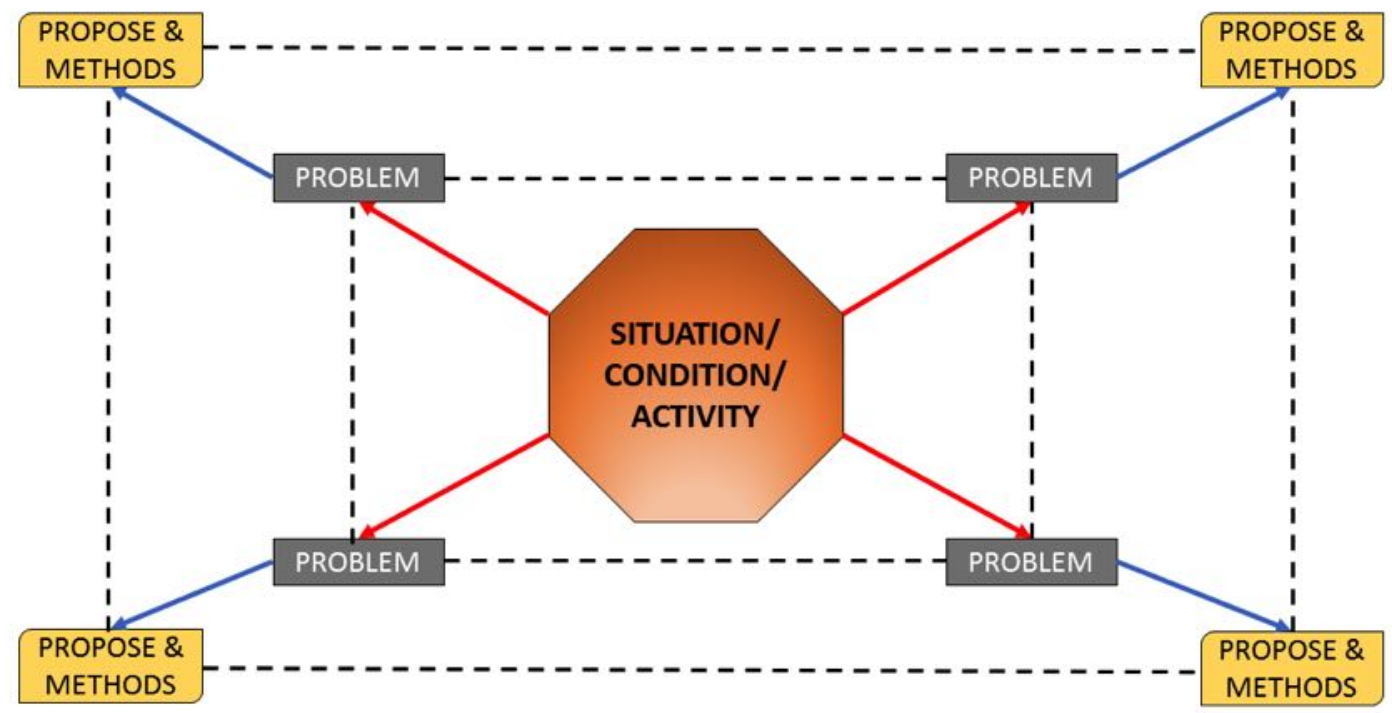

Figure 2. Model of Problem Mapping Source: Guspara, 2017

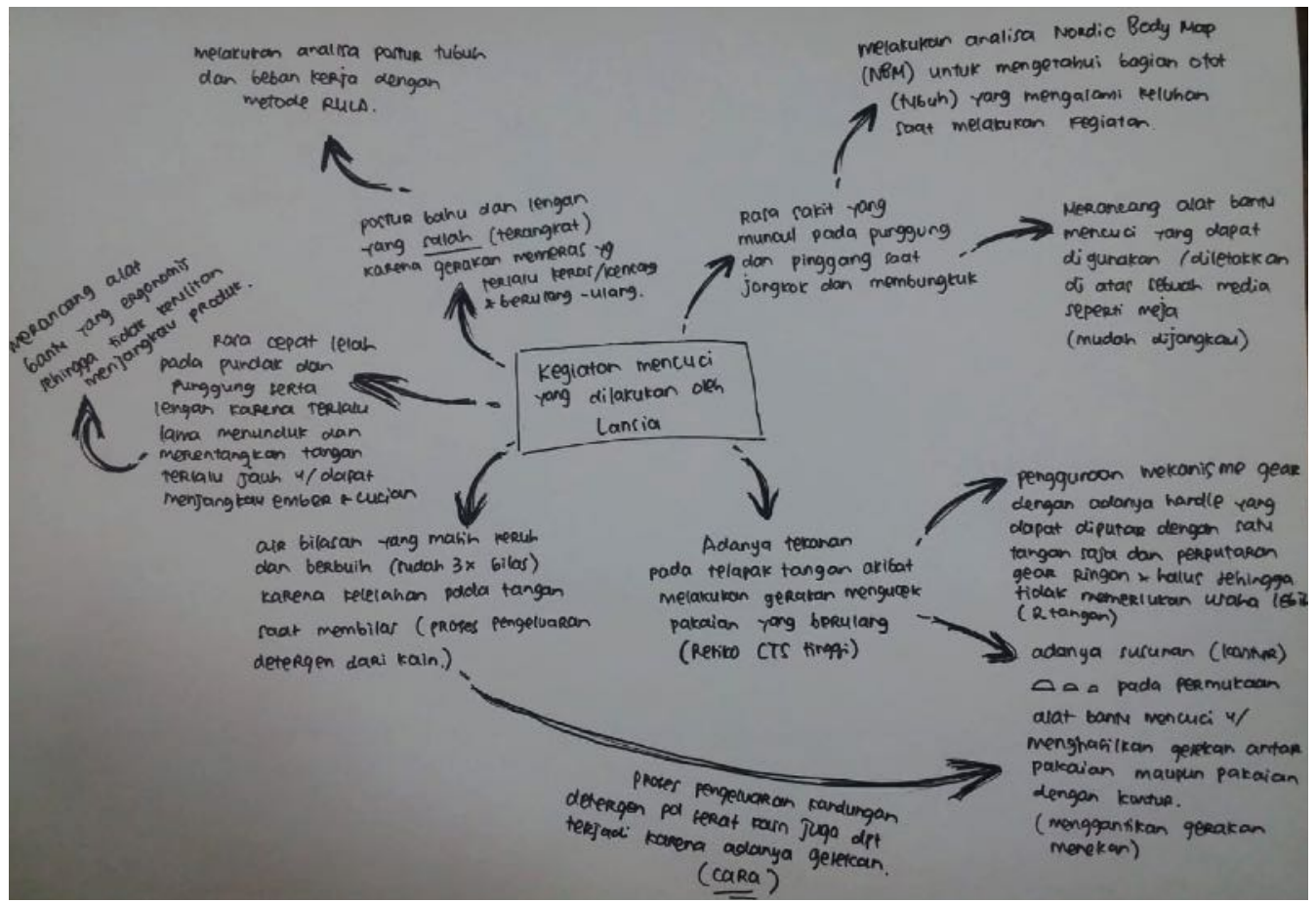

Figure 3. Case of Problem Mapping Source: Anggia Nadya, 2019

By collated a problem mapping, students able to find relationships between problems and build concepts for their research. Furthermore, they found the right 
method which applied for a process of finding alternative solutions which shown in figure 4.
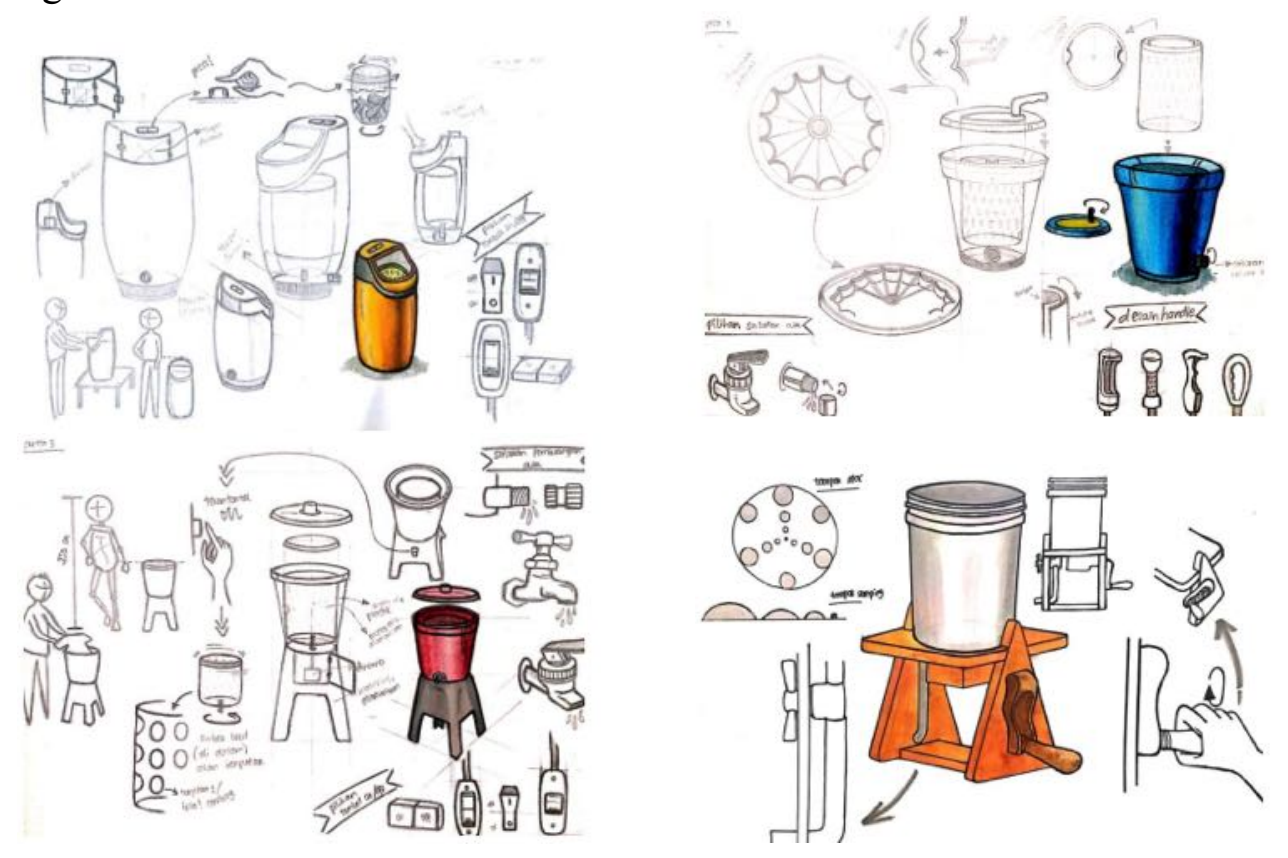

Figure 4. Case of Alternative Solution Source: Anggia Nadya, 2019

\section{Competition Project}

This competition project used a different method from the studio class process. The studio class starts with literacy, but in this competition, the project has started directly by making prototypes to look for design problems. For the record, this competition project involves other students in addition to product design students, which means is they are not accustomed to the design process. Following this situation, I need other methods to ensure they can find design problems.

The way which I took is to ask the students to look for existing products and compare those products. The basis for comparison of those products refers to a thinking model that I develop (fig. 5). In this process, students would analyze existing products through their identification of need requirements, based on userproduct-environment interaction (fig. 6). The results of their analysis would be transformed into a prototype (fig. 7) which is tested on respondents in the next step. Through usability testing, students get some inputs which are continued in the completing of utilities. The continuation of this process has asked students to look for literature to get a more holistic refinement process, such as an interlocking system for safety and a lamp buzzer that used by the squad rescue to detect survivor. 


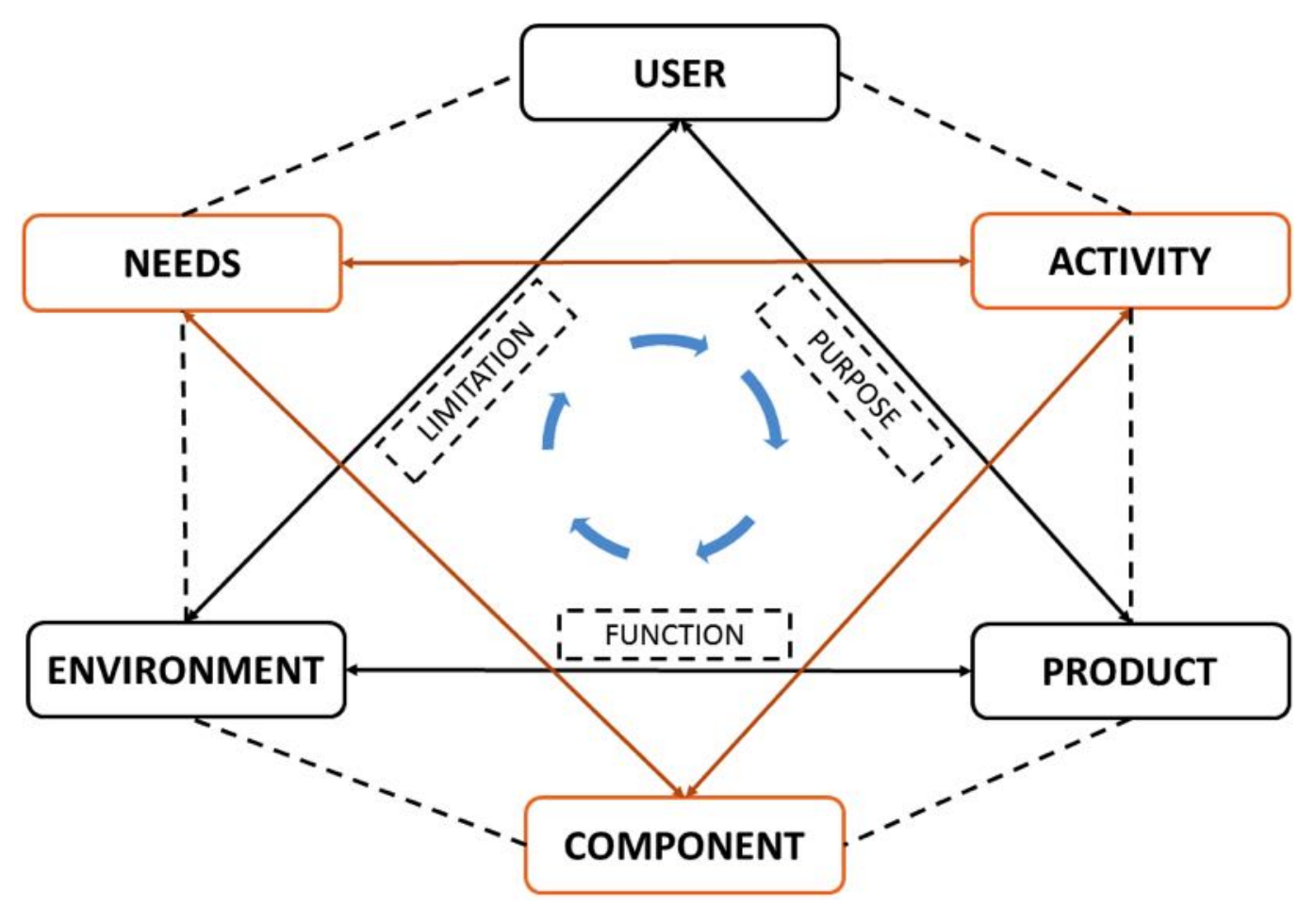

Figure 5. Thinking Model of User-Product-Environment Interaction Source: Guspara, 2017

\begin{tabular}{|c|c|c|c|}
\hline $\begin{array}{l}\text { CASE: PROTECTION TABLE } \\
\text { FROM DEBRIS CAUSE } \\
\text { EARTHQUAKE ACTIVITY } \\
\text { USER: KIDS (6-12 YEARS OLD) } \\
\text { NEEDS: WHEELCHAIR USER } \\
\text { PLACE: CLASS ROOM }\end{array}$ & USER & PRODUCT & ENVIRONMENT \\
\hline ACTIVITY & $\begin{array}{l}\text { Wheelchair users need a } \\
\text { protection/shelter table to } \\
\text { protect themselves from } \\
\text { debris caused by earthquake } \\
\text { activity. }\end{array}$ & $\begin{array}{l}\text { The protection table requires } \\
\text { a cover to protect the user } \\
\text { from debris coming from the } \\
\text { side. }\end{array}$ & Class room. \\
\hline NEEDS & $\begin{array}{l}\text { Wheelchair users need a } \\
\text { maximum of } 10 \text { seconds to get } \\
\text { under the table. }\end{array}$ & $\begin{array}{l}\text { Protection table construction } \\
\text { joints has used a welding joint } \\
\text { so that it is strong enough to } \\
\text { accept debris loads. }\end{array}$ & $\begin{array}{l}\text { Protection tables need more } \\
\text { space than a common table } \\
\text { because of their size. }\end{array}$ \\
\hline COMPONENT & $\begin{array}{l}\text { Wheelchair users need } \\
\text { enough space underneath of } \\
\text { protection table to stretch } \\
\text { their legs. }\end{array}$ & $\begin{array}{l}\text { The material used is round } \\
\text { steel pipes and using a triangle } \\
\text { construction. }\end{array}$ & $\begin{array}{l}\text { The protection table needs a } \\
\text { locking system against the } \\
\text { floor so it does not moved. }\end{array}$ \\
\hline
\end{tabular}

Figure 6. Case of Identification and Analyzed of User-Product-Environment Interaction Source: Guspara, 2019 


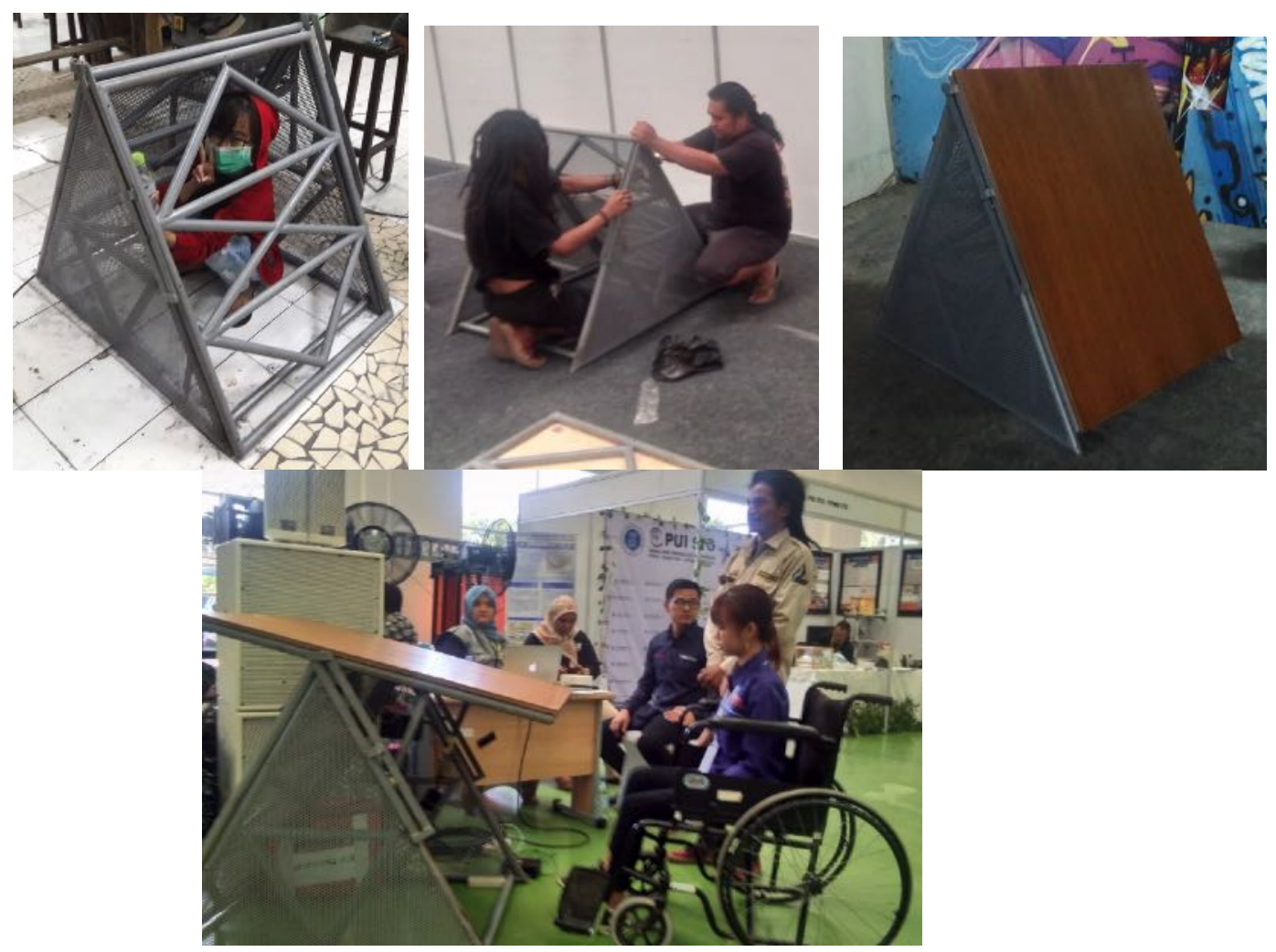

Figure 7. The prototype of the Protection Table Source: Guspara, 2019

\section{THEORETICAL FRAMEWORK}

Stigma about the task of the designer as a problem solving brings a very complicated situation, starting from the pre-structure of the problem to the transformation to solve the problem (Hillier et. al, 1984). Understanding the "problem" itself has a variety of basics situations, such as ignorance and gap (Robertson, 2017). An example is the ignorance of ways to arise goals or the availability of products which not support operations for users with special needs, that situation illustrates to the problem resides on "limitations" as well. Besides that, the problem is also closely related to "time" which means it is bound by a causative condition. A journey of time in the past and present has given many variables for problems to be complicated so that we have a wicked-problem situation arises (Rittel and Webber, 1984). Time gives shifts in ways of thinking, the trajectory in technology, changes in behavior, and the way people interact. This situation must be faced by a designer, therefore, the only way to step out from that situation is to create a new scenario for the future which based on these shifts and changes, this is similar to future casting or that is even like a foresight. I often tell students about this situation is like a time traveller who goes alone to explore time and return to the situation today to push people to change without knowing why. Therefore, 
people will just really realize the real usefulness of the product when they saw and tried it. Gradually their behavior will change following the features offered by the product.

The most important thing from problem-solving lies in the process of finding out a few of knowledge. Produce of knowledge was gained through a synthesis process, so students be able to see the problem more clearly and have a few alternative ways that able to use. Weaving in the synthesis process cannot rely solely on design theory, but requires practical experience. They work simultaneously and synchronously in the process of finding problems, formulating alternative solutions, and creating new scenarios to solve the problems (Jones, 1970). So, the experience of a problem solver is crucial in the synthesis process because that experience determines how much knowledge do they have. Accordingly, a frame of discussion in this article uses the perspective of tacit knowledge, which I suspect strongly plays a role in the design science approach.

Tacit knowledge does not only talk about skills but also focuses on expertise, such as thinking skills and translating a concept into practice areas (Leplat, 1990). Likewise with happens in the design world, not only about creating objects but how concepts are built are very close to the objects created. So, this kind of knowledge helps to condition a very closely between theory (head) and practical field (hand) (Niedderer, 2007). The situation has seen in student experience while completing their project. Finding the problem is not easy and is closely related to the method used to search. They must be as close as possible to reality and try several methods to be able to weave the problems faced and find the gaps which conduct into a design problem. This mechanism is sometimes difficult to explain explicitly because it is very situational and depends on the foresight of students as well. The process of finding a design problem is closely related to a way to look at the problem, and this condition must begin with formulating the research problem. So, there are two focuses at the beginning of their project and related to methodological problems, namely (1) research problems are connected with knowledge questions and (2) practical problems are connected with design questions (Wieringa, 2009).

The biggest problem for product design students lies in the transform from design concepts into a product. Students not only make a product but must also lay down a product into a context of the problem that needs to be solved. This situation leads students to a design decision that must take into consideration the interconnection between several aspects, such as aspects of the user, production, utility, social, ecology and economics. Speak frankly, students must make a comprehensive choice to determine problem-solving. Starting from these concepts, students must be realized the difference between functions as a tool for solving technical problems and usability as a tool for dealing with the context at hand. 
Winta Adhitia Guspara, Design Science: Approach to Build Design ...

Specifically, the "function" speak about how to overcome restrictions such as mechanical load or physical limitation and the "uses" talk about behavior changes or ways of thinking, these two things will bring a new experience for users. Students must also be directed to be able to do the derivation of the two basic thoughts. An example is the developing of material technology that has a relationship with material strength and aesthetic shape (i.e. material property) or product features that provide opportunities for more users (i.e. inclusive design).

Reviewing from that case and the discussion above, then I offer a way that can more help students for design activities. I argue that this method can bridge the gap between the theory (head) and practice (hand). The composition of design activities that I offer is Prototyping, Interaction, Re-engineering, Utilization and Synthesizing or called PIRUS. I will discuss this design activity more detail in another article, but I can simply describe it as follows:

\begin{tabular}{ll}
\hline ACTIVITY & INFORMATION \\
\hline Prototyping & Modelling by considering the newest products on the intended \\
design issues. The aspects which are considered in this stage \\
include body dimensions (static and dynamic anthropometry), \\
operating systems, component functions, inter-component \\
work, materials used, fabrication techniques, shapes, and \\
uses. The results of these considerations are the form of \\
product specifications and maps of the required user \\
capabilities that need to make a basic model. \\
A data collection on the relationship between product-user- \\
environment through direct trials using a model that has been \\
made. The trial that must be done is doing against prospective \\
users by taking into calculating the operation needs to get \\
feedback from the user. \\
Prototyping improvement based on the result of the trial by \\
developing in more detail the technical performance and still \\
taking into account external factors. \\
Planning of support capacity that has possible for operations \\
related to other broader needs, including giving more users to \\
be able to carry out operations. \\
The zoom in - zoom out the process for all aspects involved \\
and connected.
\end{tabular}




\section{DISCUSSION}

Design, especially product design, is not only talked about making an object. A product could not solve the problem, but an improvement in the thinking process could determine the object which addresses to faced the problem. This perspective could give us a big picture that a problem solving very close to the production of knowledge by the student. The ability to find the problem in every aspect of information at each level and weaving them into an essential problem, which is constituted a part of knowledge production. Through the clear problem that they found, the student would create many alternative ways for the solution clearly and also known about the interaction one and another. So, it is like a detective when comes to place in crime and starts to look detail aspect to build their theory.

At the end of this article, I invite all of you to discuss this design science approach. Based on my experience, this type of approach did not only helps students to produce knowledge but also helps us to formulate learning strategies. In other words, the production of knowledge carried out by students is also very dependent on the learning strategies that lecturers provide. Students are freer to make their concoctions of the methods used to be faced with the problem at hand. In other words, the production of knowledge carried out by students is also very dependent on the learning strategies that lecturers provide. This situation also relates to the world we face today, about big bank data, about how one can learn from the others very quickly and easily. Now, learning has not an era to feed through with many theories anymore but it is more about how to develop ways of thinking, and design through the design science approach can answer that situation. Finally, I want to talk that creativity is talking about how to improvise an experience. Improvisation requires knowledge and automatically generates new experiences, which means to produce new knowledge. Learners would make changes in their knowledge through the realities that they found.

\section{REFERENCES}

Bill Hillier; John Musgrove; Pat O'Sulivan. (1984). Knowledge and Design. In Developments in Design Methodology (pp. 245-264). New York: John Wiley \& Sons.

Guspara, W. A. (2018) (a). Cara dan Model Berpikir dalam Pengetahuan Tersirat: Studi Kasus Metode Tempa. Seminar Nasional Ergonomi. Medan.

Guspara, W. A. (2018) (b). Kreativitas dan Keputusan Personal dalam Pengetahuan Tersirat: Studi Kasus Metode Tempa. Yogyakarta: Pascasarjana ISI Yogyakarta. 
Winta Adhitia Guspara, Design Science: Approach to Build Design ...

Guspara, W. A. (2018) (c). Perkakas, Ketukangan, dan Pengetahuan Tersirat. In Craft dan Desain di Indonesia (pp. 44-56). Bandung: ADPII.

Guspara, W. A. (2018) (d). Thinking in Making: A Models Translating Information by The Blacksmith. ICAPAS. Yogyakarta.

Guspara, W. A. (2019). Craftmanship: Sudut Pandang Pandai Besi. Dinamika Kerajinan dan Batik, Vol. 36, No. 1, P. 1-16.

Horst W.J. Rittel; Melvin M. Webber. (1984). Planning Problems are Wicked problems. In Developments in Design Methodology (pp. 135-144). New York: JOHN WILEY \& SONS.

Jan Holmstrom; Mikko Ketokivi; Ari-Peka Hameri. (2009). Bridging Practice and Theory: A Design Science Approach. Decision Sciences, Vol 40, No. 1.

Jones, J. C. (1970). Design Methods: Seeds of Human Futures. Hertfordshire: John Wiley \& Sons, Ltd.

Leplat, J. (1990). Skills and Tacit Skills. Applied Psychology: An International Review, pp. 143-154.

Nathan Goodale, Heather Otis, William Andrefsky Jr., Bill Finlayson, Ian Kujit, Ken Bart. (2009). Sickle blade life-history and the transition to agriculture: An early. Journal of Archeological Science, Elsevier.

Niedderer, K. (2007). Mapping The Meaning of Knowledge in Design Research. Design Research Society.

Nystroom, M. (1985). Kitchen and Stove. Grahns: Lund University.

Polanyi, M. (1966). The Tacit Dimension. Chicago: The University of Chicago Press.

Robertson, S. I. (2017). Problem Solving. New York: Routledge.

Ryle, G. (2009). The Concept of Mind. New York: Routledge.

Simon, H. A. (1996). The Sciences of the Artificial. Massachusetts: MIT Press.

Somekh, B. (2008). Action Research. In L. M. Given, The SAGE Encyclopedia of Qualitative Research (pp. 4-7). California: SAGE Publications, Inc.

Wieringa, R. (2009). Design Science as Nested Problem Solving. University of Twente. 